\title{
Progress in the study of mercury methylation and demethylation in aquatic environments
}

\author{
LI YanBin \& CAI Yong* \\ Department of Chemistry \& Biochemistry, Southeast Environmental Research Center, Florida International University, Miami, Florida 33199, \\ USA
}

Received March 23, 2012; accepted June 12, 2012; published online August 16, 2012

\begin{abstract}
Mercury $(\mathrm{Hg})$ and its compounds are a class of highly toxic and pervasive pollutants. During the biogeochemical cycling of $\mathrm{Hg}$, methylmercury (MeHg), a potent neurotoxin, can be produced and subsequently bioaccumulated along the food chain in aquatic ecosystems. MeHg is among the most widespread contaminants that pose severe health risks to humans and wildlife. Methylation of inorganic mercury to $\mathrm{MeHg}$ and demethylation of $\mathrm{MeHg}$ are the two most important processes in the cycling of $\mathrm{MeHg}$, determining the levels of $\mathrm{MeHg}$ in aquatic ecosystems. This paper reviews recent progress on the study of $\mathrm{Hg}$ methylation and demethylation in aquatic environments, focusing on the following three areas: (1) sites and pathways of $\mathrm{Hg}$ methylation and demethylation, (2) bioavailability of $\mathrm{Hg}$ species for methylation and demethylation, and (3) application of isotope addition techniques in quantitatively estimating the net production of $\mathrm{MeHg}$.
\end{abstract}

mercury cycling, methylation, demethylation, bioavailability, methyl mercury

Citation: $\quad$ Li Y B, Cai Y. Progress in the study of mercury methylation and demethylation in aquatic environments. Chin Sci Bull, 2013, 58: 177-185, doi: 10.1007/s11434-012-5416-4

Mercury $(\mathrm{Hg})$ and its compounds are a class of highly toxic and pervasive pollutants. Over the past several decades, $\mathrm{Hg}$ contaminating and poisoning incidents have been reported in many counties (e.g. Japan, America, Canada, Sweden, and Norway) due to the large amount of $\mathrm{Hg}$ emitted into the environment, in particular from anthropogenic sources [1]. It was estimated that about 630000 infants born every year in the United States had an unsafe level of mercury in their blood [2]. Hg contamination is a global problem as one of the major $\mathrm{Hg}$ species, elemental mercury $\left(\mathrm{Hg}^{0}\right)$ has an approximate atmospheric residence time of 6 month to 1 year [3] and therefore it can be transported to ecosystems that are far from the point sources through long range atmospheric transport.

There are five major species of $\mathrm{Hg}$ in the environment, including $\mathrm{Hg}^{0}$, divalent inorganic mercury $\left(\mathrm{Hg}^{2+}\right)$, monomethylmercury $(\mathrm{MeHg})$, dimethylmercury (DMeHg), and monoethylmercury (EtHg). Inorganic $\mathrm{Hg}\left(\mathrm{Hg}^{0}\right.$ and $\left.\mathrm{Hg}^{2+}\right)$, in

*Corresponding author (email: cai@fiu.edu) particular $\mathrm{Hg}^{0}$, are the major chemical forms of $\mathrm{Hg}$ input into the environment from anthropogenic or natural sources [4,5]. During the biogeochemical cycling of $\mathrm{Hg}$, organic mercury species $(\mathrm{MeHg}, \mathrm{DMeHg}$, and $\mathrm{EtHg}$ ) can be produced. Although $\mathrm{MeHg}$ only accounts for a small fraction of $\mathrm{Hg}$ in the environment, it is the species of most concern to humans due to its high toxicity, prevalent existence, and capability of being accumulated and amplified along the food chain. The bioaccumulation of $\mathrm{MeHg}$ in the food chain, in particular in aquatic ecosystems, has caused the exposure of both humans and wildlife to $\mathrm{MeHg}$, posing severe health risks [6] and stressing the importance of understanding the key processes controlling the levels of $\mathrm{MeHg}$ in aquatic environments.

In most aquatic ecosystems, in situ production (methylation of inorganic $\mathrm{Hg}$ to $\mathrm{MeHg}$ ), rather than input from runoff water or atmospheric deposition, is the major source of $\mathrm{MeHg}$. In addition to methylation of inorganic $\mathrm{Hg}$, the reverse process, demethylation of $\mathrm{MeHg}$, simultaneously occurs in the environment. Both processes are important for 
$\mathrm{MeHg}$ cycling, determining the levels of $\mathrm{MeHg}$ in aquatic environments. This paper reviews recent progress on the study of $\mathrm{Hg}$ methylation and demethylation, focusing on the following three areas: (1) sites and pathways of $\mathrm{Hg}$ methylation and demethylation, (2) bioavailability of $\mathrm{Hg}$ species for methylation and demethylation, and (3) application of isotope addition techniques in quantitatively estimating the production and degradation of $\mathrm{MeHg}$ in aquatic ecosystems.

\section{Sites of $\mathrm{Hg}$ methylation and demethylation in aquatic environments}

\subsection{Methylation}

Adequate attention was not given to the methylation of inorganic $\mathrm{Hg}$ in aquatic environments until researchers found that the major species of $\mathrm{Hg}$ present in fish was $\mathrm{MeHg}$, rather than inorganic mercury or phenyl mercury, which were the species of $\mathrm{Hg}$ in industrial waters [7]. By adding $\mathrm{HgCl}_{2}$ to bottom sediments and incubating for 5-10 d, Jensen and Jernelov firstly found that $\mathrm{Hg}^{2+}$ could be methylated to $\mathrm{MeHg}$ in sediments of aquatic ecosystems [7]. Since then, a large number of studies have suggested that methylation in sediment was the primary source of $\mathrm{MeHg}$ in most aquatic environments [8-11]. A good positive relation was often observed between $\mathrm{MeHg}$ concentration and in situ methylation potential in sediments of aquatic systems [12-16]. In addition to sediment, $\mathrm{Hg}$ methylation has been also observed in water (both fresh water [17-19] and marine water
[20,21]) and periphyton (floating mat or macrophyte associated) [22-29] (Figure 1) in recent years. As only a small proportion of $\mathrm{MeHg}$ produced in sediment can be transported to water column, methylation of $\mathrm{Hg}$ in compartments of water column (water and periphyton) may also contribute significantly to the $\mathrm{MeHg}$ pool in pelagic food webs. A recent study showed that methylation in water column can be an important source of $\mathrm{MeHg}$ in the Arctic, accounting for around $47 \%$ of $\mathrm{MeHg}$ present in Arctic waters [21]. Methylation of mercury in periphyton may facilitate the bioaccumulation of $\mathrm{MeHg}$ in the food chain since periphyton can be the base of food webs in aquatic ecosystems [22]. However, the relative importance of periphyton or water methylation versus sediment methylation in $\mathrm{MeHg}$ levels in water column has yet to be clear. This is mainly due to the lack of quantitative estimation and comparison of the net production of $\mathrm{MeHg}$ in water column (periphyton and/or water) and the amount of $\mathrm{MeHg}$ diffused from sediment to water. Such estimations are necessary for quantitative evaluation of the importance of methylation in periphyton and water to the cycling of $\mathrm{MeHg}$ in aquatic ecosystems.

\subsection{Demethylation}

$\mathrm{MeHg}$ demethylation is a reverse process of $\mathrm{Hg}$ methylation. It simultaneously occurs in the sites (sediment, periphyton, and water) that methylation takes place (Figure 1). However, methylation is supposed to overrule the demethylation process and determine the net production of $\mathrm{MeHg}$ in sediment

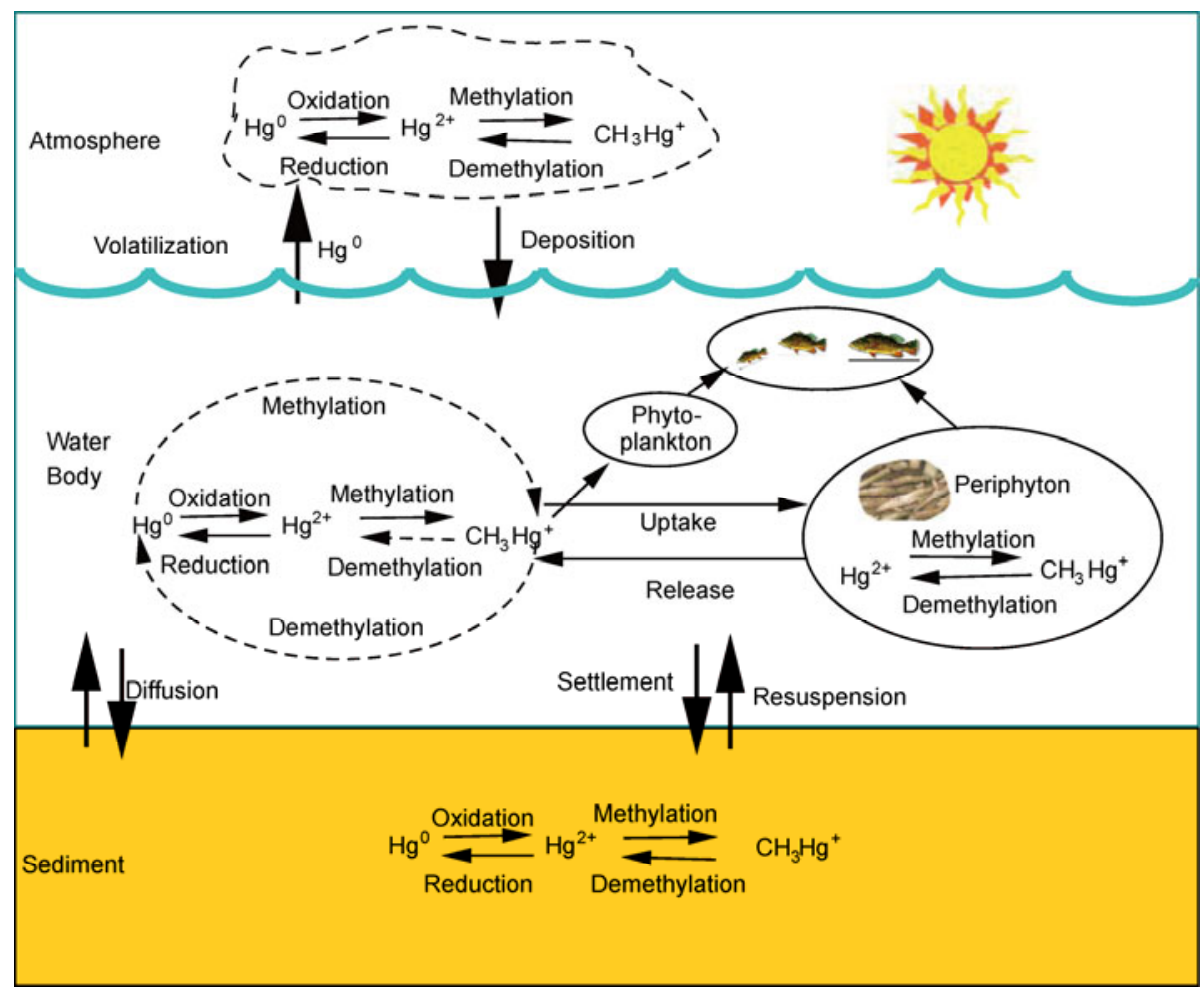

Figure 1 (Color online) Cycling of mercury in aquatic environments. 
and periphyton. This opinion is supported by the phenomenon that $\mathrm{MeHg}$ concentrations were often positively correlated to the methylation potentials [12-16], other than the demethylation potentials in these compartments. Unlike in sediment and periphyton, demethylation in water, in particular photodemethylation was suggested to be more important than the methylation process [30-32]. The importance of demethylation in water was firstly reported in the mid-1990s by Sellers et al. [30] They found that $\mathrm{MeHg}$ in water could be rapidly demethylated and about $83 \%$ of $\mathrm{MeHg}$ flowing into the lake would be removed by photodemethylation. A number of recent studies using various means have confirmed the importance of photodemethylation in a wide range of aquatic ecosystems. Based on measuring the rates of photodemethylation in water, this process was estimated to account for about $80 \%$ and $31.4 \%$ of the $\mathrm{MeHg}$ mobilized annually from sediments in a lake [31] and a wetland [32], respectively. In addition, a good inverse relationship was observed between $\mathrm{MeHg}$ concentrations and photodemethylation potentials in water column [32]. Mass independent fractionation (MIF) of $\mathrm{Hg}$ isotopes in fish could also be used to quantify the loss of $\mathrm{MeHg}$ by photodemethylation as this process leads to significant MIF of odd-mass isotopes [33]. About 25\%-68\% of $\mathrm{MeHg}$ in lakes were estimated to be lost via photodemethylation by measuring MIF in fish [33]. In addition, a study [34] on the diurnal cycling of methylmercury in a wetland found that dissolved $\mathrm{MeHg}$ concentrations in water consistently decreased during daylight periods and increased during nondaylight periods. These studies on $\mathrm{MeHg}$ demethylation have suggested that $\mathrm{MeHg}$ photodemethylation in water can be a major sink of $\mathrm{MeHg}$ in various aquatic ecosystems.

\section{Pathways of $\mathrm{Hg}$ methylation and demethyla- tion in aquatic environments}

\subsection{Methylation}

Inorganic $\mathrm{Hg}$ can be methylated to $\mathrm{MeHg}$ in water phase through biotic pathways [35-50] or abiotic pathways (photo-mediated or non photo-mediated chemical methylation) [51-66]. In natural aquatic environments, biotic process was generally suggested to be the dominant pathway of $\mathrm{Hg}$ methylation due to the fact that sterilization procedure could prohibit the methylation of $\mathrm{Hg}[7,67,68]$. Sulfate reducing bacteria (SRB) were deemed to be responsible for the methylation of $\mathrm{Hg}^{2+}$ in most aquatic systems [69-73]. Methylation of $\mathrm{Hg}^{2+}$ by $\mathrm{SRB}$ in aquatic sediments was firstly confirmed by Compeau and Bartha [74]. In that study, they found that $\mathrm{Hg}^{2+}$ methylation in anoxic salt marsh sediment decreased more than $95 \%$ in presence of sodium molybdate, a specific inhibitor of sulfate reducers. They isolated a strain of SRB, Desulfovibrio desulfuricans, from the sediment and found that it could vigorously methylate $\mathrm{Hg}^{2+}$. Since then, $\mathrm{SRB}$ has been proposed to dominate the methylation of $\mathrm{Hg}$ in a variety of aquatic ecosystems based on the sodium molybdate inhibition [22,26,40,69] or good relations observed between sulfate reducing rates and $\mathrm{Hg}$ methylation rates [70]. Other microorganisms may also dominate the methylation of $\mathrm{Hg}$, although this may only occur in limited aquatic ecosystems. For instance, iron-reducing bacteria were found to have the capability of methylating $\mathrm{Hg}^{2+}$ in both natural sediment [75] and pure culture [76]. A recent study [27] found that methylation rates in periphyton were totally inhibited by a methanogenesis inhibitor and highly stimulated by molybdate, indicating the involvement of methanogens in $\mathrm{Hg}$ methylation.

Many chemicals, e.g., amino acids [77], humic substances $[53,55,58]$, silicones [78], and low molecular weight organic acids [66], were found to be able to methylate inorganic mercury in lab settings. Irradiance is necessary for some of these reactions [66,77]. However, importance of these reactions has yet to be confirmed in natural environments. In a recent study, methylation of $\mathrm{Hg}^{2+}$ by dissolved organic matter (DOM) under sunlight was proposed to occur in lake waters and cause the increase in $\mathrm{MeHg}$ concentration during sunlight hours [19]. However, photomethylation or other chemical pathways of $\mathrm{Hg}$ methylation was rarely found to contribute significantly to $\mathrm{MeHg}$ production in other ecosystems. A recent study [79] indicated that methylation of $\mathrm{Hg}$ under sunlight played a minor role in a wetland as its rate was much slower than that of $\mathrm{MeHg}$ photodemethylation. Most previous studies only focused on the methylation of $\mathrm{Hg}^{2+}$ in the environment, while there is a lack of knowledge on the methylation of $\mathrm{Hg}^{0}$. Our recent study implied that photomethylation of $\mathrm{Hg}^{0}$ by $\mathrm{CH}_{3} \mathrm{I}$ can occur in Florida Everglades water and a pond water (Yin et al., in submission). Contribution of $\mathrm{Hg}^{0}$ methylation to $\mathrm{MeHg}$ pool also needs to be considered as $\mathrm{Hg}^{2+}$ can provides sufficient and continuous source of $\mathrm{Hg}^{0}$ through photo-mediated reduction in natural water.

\subsection{Demethylation}

Similar to methylation of $\mathrm{Hg}$, demethylation of $\mathrm{MeHg}$ can also proceed through biotic [8,80-82] or abiotic pathways (photodemethylation [30-32,34,83-91] or non photo-mediated demethylation [92,93]). Biotic process was suggested to be the dominant pathway of $\mathrm{Hg}$ demethylation in sediment and periphyton. Both SRB and methanogens could be the primary microorganisms for this process [27,80,81,94]. Although microbial demethylation of $\mathrm{MeHg}$ was also observed to occur in water column $[18,20,95]$, photodemethylation was commonly deemed to be the most important in water column [30-32,89]. Non photo-mediated demethylation of $\mathrm{MeHg}$ can also occur in lab settings (e.g., by selenoamino acids [92,93]), however this process has not been confirmed in natural environments.

Since the initial demonstration of the importance of $\mathrm{MeHg}$ photodemethylation in aquatic ecosystems [30], a 
number of studies have attempted to investigate the mechanisms underlying this process [90,91]. UV radiations (UV-A and UV-B) have been confirmed to be the primary driver of $\mathrm{MeHg}$ photodegradation in both a northern temperate lake and a subtropical wetland $[32,89]$. However, the chemical processes governing $\mathrm{MeHg}$ photodemethylation remain unclear. By reviewing the pathways of $\mathrm{Hg}$ photoreactions in the literature, five potential pathways could be responsible for $\mathrm{MeHg}$ photodemethylation (Figure 2). Although direct photodemethylation of $\mathrm{MeHg}$ species such as $\mathrm{MeHgOH}$ and $\mathrm{MeHgCl}$ (Pathway 1) is theoretically possible, recent studies showed that $\mathrm{MeHg}$ present in DI water cannot be demethylated under sunlight $[90,91]$. Free oxygen radical-induced degradation of $\mathrm{MeHg}$ (Pathway 2 or 3) was speculated to be the primary pathway of $\mathrm{MeHg}$ photodegradation in previous studies [87,88,90,91]. Both hydroxyl radical $(\cdot \mathrm{OH})$ and singlet oxygen $\left({ }^{1} \mathrm{O}_{2}\right)$ have been proposed to dominate the photodemethylation of $\mathrm{MeHg}$ in aquatic ecosystems. By adding scavengers of singlet oxygen, superoxide anion, hydrogen peroxide and hydroxyl radical, Suda et al. [85] found that singlet oxygen could be responsible for the degradation of $\mathrm{MeHg}$ and $\mathrm{EtHg}$ in sea water. Another study suggested that ${ }^{1} \mathrm{O}_{2}$ induced degradation of methylmercury-DOM complexes (Pathway 2 in Figure 2) was the major pathway of $\mathrm{MeHg}$ photodemethylation [91]. A recent work in Arctic lakes found that $\mathrm{MeHg}$ photodemethylation was driven by hydroxyl radical produced from photo-Fenton reactions [90]. Some researchers proposed that $\mathrm{Hg}^{0}$ is the product of $\mathrm{MeHg}$ photodemethylation $[33,88]$, while the others reported $\mathrm{Hg}^{2+}$ as the main product of this reaction $[87,91]$. If $\mathrm{Hg}^{0}$ is the main product in the aquatic environment, photodemethylation of $\mathrm{MeHg}$ could also be treated as a reduction process of $\mathrm{Hg}$. Direct

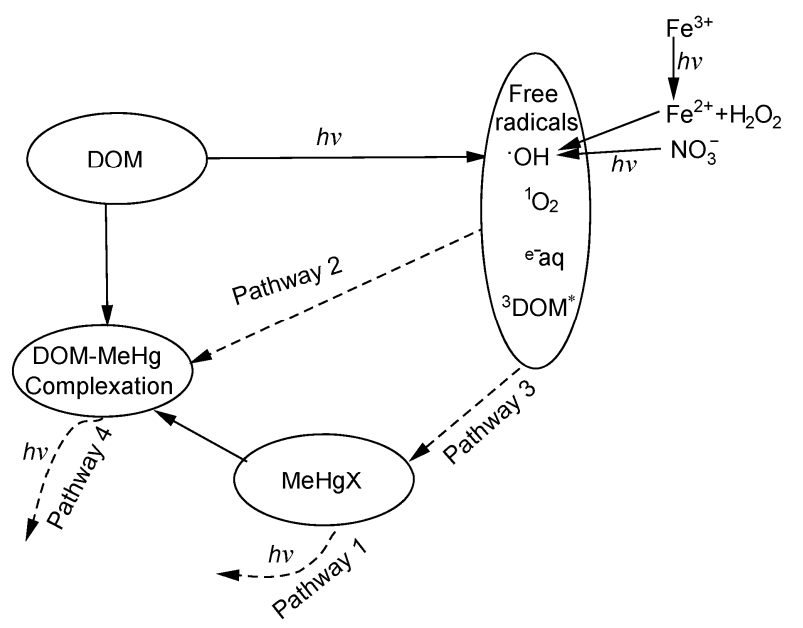

Figure 2 Possible pathways of $\mathrm{MeHg}$ photodemethylation in aquatic environments. By reviewing the pathways of $\mathrm{Hg}$ photoreactions in the literature, we proposed that five potential pathways could be responsible for $\mathrm{MeHg}$ photodemethylation: (1) direct photodemethylation of $\mathrm{MeHg}$, (2) photodemethylation of MeHg-DOM complexes by free radicals, (3) photodemethylation of $\mathrm{MeHg}$ by free radicals, (4) direct photodemethylation of MeHg-DOM complexes. transfer of electrons from photosensitized DOM to $\mathrm{Hg}$ within $\mathrm{Hg}$-DOM complexes have been proposed to be one of the possible pathways for $\mathrm{Hg}^{2+}$ photoreduction [96]. Thus, direct degradation of DOM-MeHg complexes (Pathway 4) may also be a possible pathway of $\mathrm{MeHg}$ photodemethylation in some aquatic ecosystems. A recent study using DOM isolated from natural waters [97] found that $\mathrm{MeHg}$ photodemethylation rate was not significantly decreased after adding scavengers of $\cdot \mathrm{OH}$ and ${ }^{1} \mathrm{O}_{2}$, implying that Pathway 4 may be the dominant pathway in this ecosystem. These results indicate that the pathways of $\mathrm{MeHg}$ photodemethylation may vary in different aquatic ecosystems, as evidenced by inconsistent results reported in previous studies [97]. The variation of $\mathrm{MeHg}$ photodemethylation pathway in different aquatic systems may be caused by their differences in chemical characteristics, e.g., DOM. A recent study showed that MIF of $\mathrm{MeHg}$ by photodemethylation was significantly affected by the amount of reduced organic sulfur [98], implying that concentrations and characterization of DOM may play an important role in determining the dominant pathway of $\mathrm{MeHg}$ photodemethylation in water.

\section{Bioavailability of $\mathrm{Hg}$ species for $\mathrm{Hg}$ methyla- tion and demethylation}

Bioavailability of $\mathrm{Hg}$ species is among the most important factors that determine the production of $\mathrm{MeHg}$ in aquatic ecosystems. Previous studies showed that measured $\mathrm{Hg}$ methylation rates were usually positively correlated not to the total $\mathrm{Hg}^{2+}$ concentrations, but to the calculated concentrations of $\mathrm{Hg}^{2+}$ available for methylation [99-101]. It is also known that the newly deposited $\mathrm{Hg}^{2+}$ are more bioavailable for methylation compared to the legacy $\mathrm{Hg}^{2+}$ in sediment [102]. The bioavailability of $\mathrm{Hg}$ species in aquatic ecosystems is mainly determined by two processes: (1) distribution of $\mathrm{Hg}$ between solid and aqueous phase, and (2) speciation of $\mathrm{Hg}$ species in water phase (Figure 3).

Distribution of $\mathrm{Hg}$ species between solid and aqueous phase is expected to significantly affect the bioavailability of $\mathrm{Hg}$ species as only dissolved $\mathrm{Hg}$ species can transport through cell membranes and subsequently be methylated or demethylated. The importance of adsorption/desorption on $\mathrm{Hg}$ bioavailability has been confirmed by both laboratory and field studies. When Pseudomonas fluorescens was tested for its ability to methylate dissolved $\mathrm{Hg}^{2+}$ and $\mathrm{Hg}^{2+}$ absorbed on mineral colloids, the results showed that methylation rate of dissolve $\mathrm{Hg}^{2+}$ was much larger than that of $\mathrm{Hg}^{2+}$ absorbed on solids [103]. In addition, $\mathrm{Hg}$ methylation rates in surface sediments were observed to be inversely related to the distribution coefficients $(K(\mathrm{D}))$ of $\mathrm{Hg}^{2+}$ and positively correlated to concentrations of $\mathrm{Hg}^{2+}$ in pore waters in some aquatic ecosystems $[99,100]$. The adsorption/desorption of $\mathrm{Hg}$ species is known to be affected by a variety of factors in aquatic environments, e.g., $\mathrm{pH}$, redox potential, salinity, 


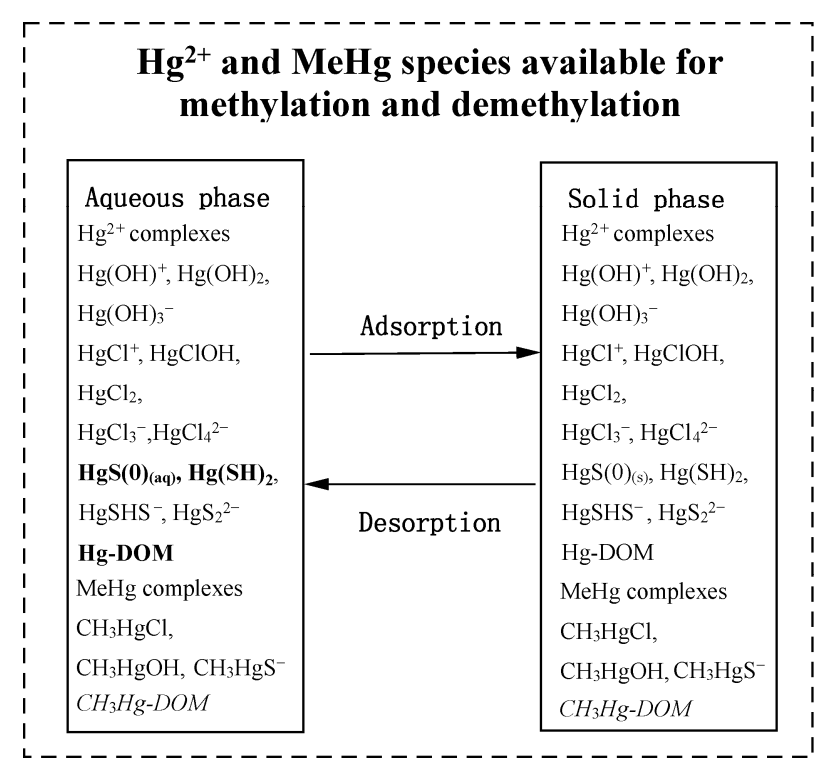

Figure $3 \mathrm{Hg}^{2+}$ and $\mathrm{MeHg}$ complexes present in aquatic environments. Bold: species that have been reported to be the major species available for biotic methylation and demethylation. Italic: species that have been reported to be the major $\mathrm{Hg}$ species available for photodemethylation.

organic and inorganic complexing reagents, composition of solid. These factors are also expected to play an important role in controlling the bioavailability of $\mathrm{Hg}^{2+}$ in aquatic environments. Unlike the biotic methylation and demethylation, photodemethylation rates of $\mathrm{MeHg}$ were observed to be similar in filtrated and un-filtrated waters [89], implying that adsorption/desorption of $\mathrm{MeHg}$ in water column plays a minor role in the photodemethylation of $\mathrm{MeHg}$.

$\mathrm{Hg}^{2+}$ and $\mathrm{MeHg}$ in aquatic environments are generally not free ions, but complexed to various inorganic or organic ligands, including hydroxide, chloride, sulfides, and DOM [104]. The dominant species of $\mathrm{Hg}^{2+}$ and $\mathrm{MeHg}$ in water or porewater depends upon various physical and chemical parameters, e.g., $\mathrm{pH}$, Eh, sulfide, $\mathrm{Cl}^{-}$, and DOM [104-108]. As not all of these complexes are available for methylation and demethylation, speciation of $\mathrm{Hg}$ species in water and porewater is another important factor determining bioavailability of $\mathrm{Hg}$ species. Neutral $\mathrm{Hg}$-sulfide complexes (e.g. $\mathrm{HgS}(0)_{(\mathrm{aq})}$ and $\left.\mathrm{Hg}(\mathrm{SH})_{2}\right)$ have been suggested to be the major species of $\mathrm{Hg}$ that are available for methylation since the late 1990s [101,105,109-112]. It was proposed that these neutral $\mathrm{Hg}$ species could be transported to microorganism cells by passive diffusion and then methylated [109-110]. This opinion was supported by the positive relationship between $\mathrm{Hg}$ methylation rates and calculated concentrations of neutral $\mathrm{Hg}$-sulfide complex in solution, which was observed both in laboratory pure culture of SRB $[101,111]$ and field investigations $[112,113] . \mathrm{Hg}^{2+}$-thiol complexes are another $\mathrm{Hg}^{2+}$ species that have been proposed to be available for methylation [114,115]. In a recent study, methylation of $\mathrm{Hg}^{2+}$ by Geobacter sulfurreducens was found to be greatly enhanced in the presence of low concentrations of cysteine. The authors proposed that the formation of $\mathrm{Hg}^{2+}-$ cysteine complexes, which could be transported to cells by active transport [115], facilitated both the uptake and methylation of $\mathrm{Hg}^{2+}$ [114]. However, the importance of $\mathrm{Hg}$-thiol complexes in the methylation of $\mathrm{Hg}$ has yet to be confirmed in natural environments. As mercury in aquatic ecosystems is expected to preferentially bind with thiol and other sulfur-containing groups in organic matter [116], it is necessary to investigate whether this process plays an important role in $\mathrm{Hg}$ methylation in natural environments.

Similar to the biotic methylation and demethylation of $\mathrm{Hg}$, photodemethylation of $\mathrm{MeHg}$ can also be affected by the speciation of $\mathrm{MeHg}$ in water column. A previous study reported that sunlight-induced $\mathrm{MeHg}$ photodegradation could not occur when $\mathrm{MeHgCl}, \mathrm{MeHgOH}$ or $\mathrm{MeHg}$ ion was the dominant species of $\mathrm{MeHg}$ in water, while phenyl and sulfur bonded MeHg species could be decomposed [117]. A recent study suggested that methylmercury species bound to sulphur-containing ligands such as glutathione and mercaptoacetate had a much higher demethylation rates than methylmercury-chloride complexes [91]. Despite these findings in laboratory studies, it is still unclear which species of $\mathrm{MeHg}$ dominate the photodemethylation process in natural waters and more attention should be paid to this area.

\section{Application of isotope addition technique in the study of $\mathrm{Hg}$ methylation and demethylation and estimating the net production of $\mathrm{MeHg}$ in aquatic environments}

Since the finding of the importance of methylation and demethylation in aquatic ecosystems, efforts have been made to precisely measure the $\mathrm{Hg}$ methylation and demethylation rates, which are important for quantitatively estimating the production of MeHg. Isotope addition technique has been applied in this field since the late 1970s [17,118] due to its high accuracy and precision, short incubation time, and ability of simultaneously determining the methylation and demethylation rates. Both radio [17,118-120] and stable isotope addition methods $[15,20,32,89,102,121-128]$ have been applied in this field. When radio isotope addition method was adopted, a radio isotope of $\mathrm{Hg}^{2+}$ (e.g. ${ }^{203} \mathrm{Hg}^{2+}$ ) is spiked into samples to monitor the methylation process. $\mathrm{C}-14$ labeled $\mathrm{MeHg}$ is usually used to examine the demethylation process. Stable isotope addition methods have been widely using in studying $\mathrm{Hg}$ methylation and demethylation since the mid-1990s [122]. By using this technique, stable isotope labeled $\mathrm{Hg}^{2+}$ (e.g., ${ }^{199} \mathrm{Hg}^{2+}$ ) and/or $\mathrm{MeHg}$ (e.g., $\mathrm{Me}^{201} \mathrm{Hg}$ ) were added into samples to monitor methylation and/or demethylation process, respectively. Although both techniques promise a precise measurement of $\mathrm{Hg}$ methylation and demethylation rates, application of radio isotope addition techniques are limited due to its disadvantage of utilizing highly radioactive material and usually requiring 
specific safety measures [129].

Net $\mathrm{MeHg}$ production rate is a crucial parameter for estimating the net production of $\mathrm{MeHg}$ in various compartments of aquatic ecosystems, which is necessary for identifying the major source and sink of $\mathrm{MeHg}$ in aquatic ecosystems. This parameter can be calculated by incubating the samples without the addition of any $\mathrm{Hg}$ species and measuring the changes in ambient $\mathrm{MeHg}$. However, changes in ambient $\mathrm{MeHg}$ are usually difficult to be accurately measured as variation in ambient $\mathrm{MeHg}$ is often too small to be detected [119]. By utilizing isotope addition techniques, a method based on measuring the specific methylation and demethylation rates has been developed and used to estimate the net $\mathrm{MeHg}$ production rate $[14,27,130]$. In these studies, methylation $\left(k_{\mathrm{m}}\right)$ and demethylation $\left(k_{\mathrm{d}}\right)$ rate constants were measured and calculated (eqs. (1) and (2)) by double isotope addition methods. Then, the net production rates of $\mathrm{MeHg}$ were calculated by the difference of potential methylation rate $\left(k_{\mathrm{m}} \times C_{\mathrm{Hg}^{2+}}\right.$ (ambient) and potential demethylation rate $\left(k_{\mathrm{d}} \times C_{\mathrm{MeHg}}(\right.$ ambient) $)$ (eq. (3)). However, such calculation does not take consideration of the differences in bioavailability of ambient and newly spiked $\mathrm{Hg}$ species [102]. A significant error could occur with this omission. For example, a recent study showed that the net production rate of $\mathrm{MeHg}$ in Everglades sediment would be overestimated by a factor of 20 without the consideration of the difference of newly spiked and ambient $\mathrm{Hg}$ species in methylation and demethylation efficiency [79]. Thus, it is necessary to take consideration of this difference ( $\alpha$ and $\beta$ in eq. (4)) when calculating the net production of $\mathrm{MeHg}$ using isotope addition techniques. In previous studies [102], $\alpha$ and $\beta$ were obtained by measuring the methylation and demethylation rates of ambient and newly spiked $\mathrm{Hg}$ species, which is also based on the accurate measurement of changes in ambient $\mathrm{MeHg}$ concentrations. Due to the difficulty of accurate measuring the variation in ambient $\mathrm{MeHg}$, it is necessary to develop a method that can accurately measure the differences of ambient and newly spiked mercury species in methylation and demethylation efficiency.

$$
\begin{gathered}
k_{\mathrm{m}}=\frac{\Delta C_{\mathrm{Me}^{\mathrm{m}} \mathrm{Hg}}}{C_{{ }_{\mathrm{m}} \mathrm{Hg}^{2+}} \times t}, \\
k_{\mathrm{d}}=\frac{\ln \frac{C_{\mathrm{Me}^{\mathrm{n}} \mathrm{Hg}}}{C_{\mathrm{Me}_{\mathrm{n}} \mathrm{Hg}}-\Delta C_{\mathrm{Me}^{\mathrm{n}} \mathrm{Hg}}}}{t},
\end{gathered}
$$

Net $\mathrm{MeHg}$ production rate $\left(\mathrm{ng} \mathrm{g}^{-1} \mathrm{~d}^{-1}\right)=$

$$
k_{\mathrm{m}} \times C_{\mathrm{Hg}^{2+}}(\text { ambient })-k_{\mathrm{d}} \times C_{\mathrm{MeHg}}(\text { ambient }),
$$

Net $\mathrm{MeHg}$ production rate $\left(\mathrm{ng} \mathrm{g}^{-1} \mathrm{~d}^{-1}\right)=$

$$
k_{\mathrm{m}} \times \alpha \times C_{\mathrm{Hg}^{2+}}(\text { ambient })-k_{\mathrm{d}} \times \beta \times C_{\mathrm{MeHg}}(\text { ambient }),
$$

where $k_{\mathrm{m}}$ is the specific methylation rate constant of spiked ${ }^{\mathrm{m}} \mathrm{Hg}^{2+}\left(\mathrm{d}^{-1}\right) ; k_{\mathrm{d}}$ is the specific demethylation rate constant of spiked $\mathrm{Me}{ }^{\mathrm{n}} \mathrm{Hg}\left(\mathrm{d}^{-1}\right) ; t$ is the incubation time (d); $C_{\mathrm{m} \mathrm{Hg}^{2+}}$ and $C_{\mathrm{Me}^{\mathrm{n}} \mathrm{Hg}}$ are the spiked concentrations of ${ }^{\mathrm{m}} \mathrm{Hg}^{2+}$ and $\mathrm{Me}^{\mathrm{n}} \mathrm{Hg}\left(\mathrm{ng} \mathrm{g}^{-1}\right)$, respectively; $\alpha$ is the ratio of methylation rate constant of ambient to newly spiked $\mathrm{Hg}^{2+} ; \beta$ is the ratio of demethylation rate constant of ambient to newly spiked $\mathrm{MeHg}$.

\section{Concluding remarks}

Methylation and demethylation of mercury are a significant part of $\mathrm{MeHg}$ cycling, determining the levels of $\mathrm{MeHg}$ in aquatic ecosystems. They can occur in various compartments of aquatic ecosystems, including sediment, periphyton and water. Biotic methylation in sediment and photodemethylation in water are suggested to be the major source and sink of $\mathrm{MeHg}$ in aquatic environments. Recent studies found that biotic methylation in periphyton and water could also contribute significantly to the $\mathrm{MeHg}$ pool, in particular for the pelagic food webs. The relative importance of methylation in periphyton and/or water versus sediment in $\mathrm{MeHg}$ levels in pelagic food webs has yet to be clear. This is mainly due to the lack of quantitative estimation and comparison of the net production of $\mathrm{MeHg}$ in water column (periphyton and/or water) and the amount of $\mathrm{MeHg}$ diffused from sediment to water. Such estimations are necessary for evaluating the importance of methylation in periphyton and water to the cycling of $\mathrm{MeHg}$ in aquatic ecosystems.

Much work is also required in the study of bioavailability of $\mathrm{Hg}$ species for methylation and demethylation. Distribution of $\mathrm{Hg}$ between solid and water and speciation of $\mathrm{Hg}$ species in aqueous phase are the two factors that determine the bioavailability of $\mathrm{Hg}$ species. Both neutral $\mathrm{Hg}^{2+}$-sulfide complexes and $\mathrm{Hg}^{2+}$-thiol complexes have been proposed as the species of $\mathrm{Hg}^{2+}$ that can be transported to bacteria cells, and subsequently being methylated. More work is required to identify which is the dominant species of $\mathrm{Hg}^{2+}$ that associate with the biotic methylation of $\mathrm{Hg}$ in natural environments. In comparison to $\mathrm{Hg}^{2+}$, bioavailability of $\mathrm{MeHg}$ for both biotic demethylation and photodemethylation has been poorly studied and requires more attentions.

More efforts should also be made on estimating the net $\mathrm{MeHg}$ production rate, which is important for identifying the major source of $\mathrm{MeHg}$ in aquatic ecosystems. Isotope addition technique is a useful technique in this area due to its high accuracy and precision, short incubation time, and ability of simultaneously determining the methylation and demethylation rates. The difference of newly spiked and ambient mercury species in methylation and demethylation efficiency should be taken into account when estimating this rate using isotope addition techniques. There is an urgent need to develop a method that can accurately measure the differences between ambient and newly spiked mercury 
species in methylation and demethylation efficiency.

This work was partially supported by the U.S. Department of Energy (DE-FG01-05EW07033) and the National Natural Science Foundation of China (21120102040).

1 Mason R P, Fitzgerald W F, Morel F M M. The biogeochemical cycling of elemental mercury: Anthropogenic influences. Geochimica Et Cosmochimica Acta, 1994, 58: 3191-3198

2 Renner R. Mercury woes appear to grow. Environ Sci Technol, 2004, 38: 144A

3 Fitzgerald W F. Atmospheric and Oceanic Cycling of Mercury. San Diego: Academic Press, 1989

4 Stein E D, Cohen Y, Winer A M. Environmental distribution and transformation of mercury compounds. Crit Rev Environ Sci Technol, 1996, 26: 1-43

5 Pacyna E G, Pacyna J M, Fudala J, et al. Mercury emissions to the atmosphere from anthropogenic sources in Europe in 2000 and their scenarios until 2020. Sci Total Environ, 2006, 370: 147-156

6 Mergler D, Anderson H A, Chan L H M, et al. Methylmercury Exposure and health effects in humans: A worldwide concern. AMBIO, 2007, 36: 3-11

7 Jensen S, Jernelov A. Biological methylation of mercury in aquatic organisms. Nature, 1969, 223: 753-754

8 Compeau G, Bartha R. Methylation and demethylation of mercury under controlled redox, $\mathrm{Ph}$, and salinity conditions. Appl Environ Microbiol, 1984, 48: 1203-1207

9 Berman M, Bartha R. Control of the methylation process in a mercurypolluted aquatic sediment. Environ Pollut B, 1986, 11: 41-53

10 Steffan R J, Korthals E T, Winfrey M R. Effects of acidification on mercury methylation, demethylation, and volatilization in sediments from an acid-susceptible lake. Appl Environ Microbiol, 1988, 54: 2003-2009

11 Gilmour C C, Henry E A, Mitchell R. Sulfate stimulation of mercury methylation in fresh-water sediments. Environ Sci Technol, 1992, 26: $2281-2287$

12 Gilmour C C, Riedel G S, Ederington M C, et al. Methylmercury concentrations and production rates across a trophic gradient in the northern Everglades. Biogeochemistry, 1998, 40: 327-345

13 Marvin-DiPasquale M C, Agee J L, Bouse R M, et al. Microbial cycling of mercury in contaminated pelagic and wetland sediments of San Pablo Bay, California. Environ Geol (Berl), 2003, 43: 260-267

14 Gray J E, Hines M E, Higueras P L, et al. Mercury speciation and microbial transformations in mine wastes, stream sediments, and surface waters at the Almaden Mining District, Spain. Environ Sci Technol, 2004, 38: 4285-4292

15 Heyes A, Mason R P, Kim E H, et al. Mercury methylation in estuaries: Insights from using measuring rates using stable mercury isotopes. Mar Chem, 2006, 102: 134-147

16 Drott A, Lambertsson L, Bjorn E, et al. Do potential methylation rates reflect accumulated methyl mercury in contaminated sediments? Environ Sci Technol, 2008, 42: 153-158

17 Furutani A, Rudd J W M. Measurement of mercury methylation in lake water and sediment samples. Appl Environ Microbiol, 1980, 40: $770-776$

18 Matilainen T, Verta M. Mercury methylation and demethylation in aerobic surface waters. Can J Fish Aquat Sci, 1995, 52: 1597-1608

19 Siciliano S D, O'Driscoll N J, Tordon R, et al. Abiotic production of methylmercury by solar radiation. Environ Sci Technol, 2005, 39: 1071-1077

20 Monperrus M, Tessier E, Amouroux D, et al. Mercury methylation, demethylation and reduction rates in coastal and marine surface waters of the Mediterranean Sea. Mar Chem, 2007, 107: 49-63

21 Lehnherr I, St Louis V L, Hintelmann H, et al. Methylation of inorganic mercury in polar marine waters. Nat Geosci, 2011, 4: 298-302

22 Cleckner L B, Gilmour C C, Hurley J P, et al. Mercury methylation in periphyton of the Florida Everglades. Limnol Oceanogr, 1999, 44: $1815-1825$
23 Mauro J B N, Guimaraes J R D, Hintelmann H, et al. Mercury methylation in macrophytes, periphyton, and water-comparative studies with stable and radio-mercury additions. Anal Bioanal Chem, 2002, 374: 983-989

24 Desrosiers M, Planas D, Mucci A. Mercury methylation in the epilithon of boreal shield aquatic ecosystems. Environ Sci Technol, 2006, 40: 1540-1546

25 Yu R-Q, Adatto I, Montesdeoca M R, et al. Mercury methylation in Sphagnum moss mats and its association with sulfate-reducing bacteria in an acidic Adirondack forest lake wetland. FEMS Microbiol Ecol, 2010, 74: 655-668

26 Acha D, Hintelmann H, Yee J. Importance of sulfate reducing bacteria in mercury methylation and demethylation in periphyton from Bolivian Amazon region. Chemosphere, 2011, 82: 911-916

27 Hamelin S, Amyot M, Barkay T, et al. Methanogens: Principal methylators of mercury in Lake Periphyton. Environ Sci Technol, 2011, 45: 7693-7700

28 Correia R R S, Miranda M R, Guimaraes J R D. Mercury methylation and the microbial consortium in periphyton of tropical macrophytes: Effect of different inhibitors. Environ Res, 2012, 112: 86-91

29 Guimaraes J R D, Roulet M, Lucotte M, et al. Mercury methylation along a lake-forest transect in the Tapajos river floodplain, Brazilian Amazon: Seasonal and vertical variations. Sci Total Environ, 2000, 261: 91-98

30 Sellers P, Kelly C A, Rudd J W M, et al. Photodegradation of methylmercury in lakes. Nature, 1996, 380: 694-697

31 Hammerschmidt C R, Fitzgerald W F. Photodecomposition of methylmercury in an arctic Alaskan lake. Environ Sci Technol, 2006, 40: $1212-1216$

32 Li Y B, Mao Y X, Liu G L, et al. Degradation of methylmercury and its effects on mercury distribution and cycling in the Florida Everglades. Environ Sci Technol, 2010, 44: 6661-6666

33 Bergquist B A, Blum J D. Mass-dependent and -independent fractionation of $\mathrm{Hg}$ isotopes by photoreduction in aquatic systems. Science, 2007, 318: 417-420

34 Naftz D L, Cederberg J R, Krabbenhoft D P, et al. Diurnal trends in methylmercury concentration in a wetland adjacent to Great Salt Lake, Utah, USA. Chem Geol, 2011, 283: 78-86

35 Reisinger K, Stoeppler M, Nurnberg H W. Biological methylation of inorganic mercury by Saccharomyces-Cerevisiae-A possible environmental process. Fresenius Zeitschrift Fur Analytische Chemie, 1983, 316: 612-615

36 Trevors J T. Mercury methylation by bacteria. J Basic Microbiol, 1986, 26: 499-504

37 Choi S C, Bartha R. Cobalamin-mediated mercury methylation by Desulfovibrio-Desulfuricans Ls. Appl Environ Microbiol, 1993, 59: 290-295

38 Choi S C, Chase T, Bartha R. Metabolic pathways leading to mercury methylation in Desulfovibrio-Desulfuricans Ls. Appl Environ Microbiol, 1994, 60: 4072-4077

39 Choi S C, Chase T, Bartha R. Enzymatic catalysis of mercury methylation by Desulfovibrio-Desulfuricans Ls. Appl Environ Microbiol, 1994, 60: 1342-1346

40 Chen Y, Bonzongo J C J, Lyons W B, et al. Inhibition of mercury methylation in anoxic freshwater sediment by group VI anions. Environ Toxicol Chem, 1997, 16: 1568-1574

41 Pak K R, Bartha R. Mercury methylation by interspecies hydrogen and acetate transfer between sulfidogens and methanogens. Appl Environ Microbiol, 1998, 64: 1987-1990

42 Pak K R, Bartha R. Mercury methylation and demethylation in anoxic lake sediments and by strictly anaerobic bacteria. Appl Environ Microbiol, 1998, 64: 1013-1017

43 King J K, Saunders F M, Lee R F, et al. Coupling mercury methylation rates to sulfate reduction rates in marine sediments. Environ Toxicol Chem, 1999, 18: 1362-1369

44 King J K, Kostka J E, Frischer M E, et al. Sulfate-reducing bacteria methylate mercury at variable rates in pure culture and in marine sediments. Appl Environ Microbiol, 2000, 66: 2430-2437

45 Macalady J L, Mack E E, Nelson D C, et al. Sediment microbial community structure and mercury methylation in mercury-polluted Clear Lake, California. Appl Environ Microbiol, 2000, 66: 1479-1488 
46 Siciliano S D, Lean D R S. Methyltransferase: An enzyme assay for microbial methylmercury formation in acidic soils and sediments. Environ Toxicol Chem, 2002, 21: 1184-1190

47 Ekstrom E B, Morel F M M, Benoit J M. Mercury methylation independent of the acetyl-coenzyme a pathway in sulfate-reducing bacteria. Appl Environ Microbiol, 2003, 69: 5414-5422

48 Marvin-DiPasquale M, Agee J L. Microbial mercury cycling in sediments of the San Francisco Bay-Delta. Estuaries, 2003, 26: 1517-1528

49 Ranchou-Peyruse M, Monperrus M, Bridou R, et al. Overview of mercury methylation capacities among anaerobic bacteria including representatives of the sulphate-reducers: Implications for environmental studies. Geomicrobiol J, 2009, 26: 1-8

50 Avramescu M L, Yumvihoze E, Hintelmann H, et al. Biogeochemical factors influencing net mercury methylation in contaminated freshwater sediments from the St. Lawrence River in Cornwall, Ontario, Canada. Sci Total Environ, 2011, 409: 968-978

51 Larock R C, Hershberger S S. Mercury in organic-chemistry. 19. Rhodium promoted methylation of organomercurials. Tetrahedron Lett, 1981, 22: 2443-2446

52 Larock R C, Hershberger S S. Mercury in organic-chemistry 21. Methylation of organomercurials via organorhodium species. J Organomet Chem, 1982, 225: 31-41

53 Nagase H, Ose Y, Sato T, et al. Methylation of mercury by humic substances in an aquatic environment. Sci Total Environ, 1982, 25: 133-142

54 Nagase H, Ose Y, Sato T, et al. Production of methylmercury by abiological methylation of inorganic mercury in the environment. Jpn J Toxicol Environ Health, 1983, 29: 55

55 Nagase H, Ose Y, Sato T, et al. Mercury methylation by compounds in humic material. Sci Total Environ, 1984, 32: 147-156

56 Woggon H, Klein S, Jehle D, et al. Transformation reactions of special metals in organisms and in the environment. 2. Abiological methylation reactions of mercury, especially by methyltin compounds, and humic and fulvic-acids. Nahrung-Food, 1984, 28: 851-862

57 Lee Y H, Hultberg H, Andersson I. Catalytic effect of various metalions on the methylation of mercury in the presence of humic substances. Water Air Soil Pollut, 1985, 25: 391-400

58 Weber J H, Reisinger K, Stoeppler M. Methylation of mercury(II) by fulvic-acid. Environ Technol Lett, 1985, 6: 203-208

59 Bellama J M, Jewett K L, Nies J D. Methylation of mercury(II) species in water by organosilicon compounds. Abstr Pap Am Chem Soc, 1986, 192: 127-GEOC

60 Nagase H, Ose Y, Sato T, et al. Mercury methylation by ash from refuse incineration. Sci Total Environ, 1986, 53: 133-138

61 Watanabe N, Nagase H, Nakamura T, et al. Chemical methylation of mercury(II) salts by polydimethylsiloxanes in aqueous-solution. Ecotoxicol Environ Saf, 1986, 11: 174-178

62 Bellama J M, Jewett K L, Manders W F, et al. A comparison of the rates of methylation of mercury(II) species in aquatic media by various organotin and organo-silicon moieties. Sci Total Environ, 1988, 73: 39-51

63 Cerrati G, Bernhard M, Weber J H. Model reactions for abiotic mercury(II) methylation-kinetics of methylation of mercury(II) by mono-methyltin, di-methyltin, and tri-methyltin in seawater. Appl Organomet Chem, 1992, 6: 587-595

64 Weber J H. Review of possible paths for abiotic methylation of mercury(II) in the aquatic environment. Chemosphere, 1993, 26: 2063-2077

65 Gardfeldt K, Munthe J, Stromberg D, et al. A kinetic study on the abiotic methylation of divalent mercury in the aqueous phase. Sci Total Environ, 2003, 304: 127-136

66 Yin Y, Chen B, Mao Y, et al. Possible alkylation of inorganic $\mathrm{Hg}$ (II) by photochemical processes in the environment. Chemosphere, 2012 (in press)

67 Berman M, Bartha R. Levels of chemical versus biological methylation of mercury in sediments. Bull Environ Contam Toxicol, 1986, 36: 401-404

68 Mauro J B N, Guimaraes J R D, Melamed R. Mercury methylation in macrophyte roots of a tropical lake. Water Air Soil Pollut, 2001, 127: 271-280

69 Kerry A, Welbourn P M, Prucha B, et al. Mercury methylation by sulfate-reducing bacteria from sediments of an acid stressed lake. Water Air Soil Pollut, 1991, 56: 565-575

70 King J K, Kostka J E, Frischer M E, et al. A quantitative relationship that remonstrates mercury methylation rates in marine sediments are based on the community composition and activity of sulfatereducing bacteria. Environ Sci Technol, 2001, 35: 2491-2496

71 Dias M, Salvado J C, Monperrus M, et al. Characterization of Desulfomicrobium salsuginis sp. nov. and Desulfomicrobium aestuarii sp. nov., two new sulfate-reducing bacteria isolated from the Adour estuary (French Atlantic coast) with specific mercury methylation potentials. Syst Appl Microbiol, 2008, 31: 30-37

72 Ekstrom E B, Morel F M M. Cobalt limitation of growth and mercury methylation in sulfate-reducing bacteria. Environ Sci Technol, 2008, 42: 93-99

73 Jeremiason J D, Engstrom D R, Swain E B, et al. Sulfate addition increases methylmercury production in an experimental wetland. Environ Sci Technol, 2006, 40: 3800-3806

74 Compeau G C, Bartha R. Sulfate-reducing bacteria: Principal methylators of mercury in anoxic estuarine sediment. Appl Environ Microbiol, 1985, 50: 498-502

75 Fleming E J, Mack E E, Green P G, et al. Mercury methylation from unexpected sources: Molybdate-inhibited freshwater sediments and an iron-reducing bacterium. Appl Environ Microbiol, 2006, 72: 457-464

76 Kerin E J, Gilmour C C, Roden E, et al. Mercury methylation by dissimilatory iron-reducing bacteria. Appl Environ Microbiol, 2006, 72: 7919-7921

77 Hayashi K, Kawai S, Ohno T, et al. Photomethylation of inorganic mercury by aliphatic alpha-amino acids. J Chem Soc Chem Commun, 1977: $158-159$

78 Nagase H, Ose Y, Sato T. Possible methylation of inorganic mercury by silicones in the environment. Sci Total Environ, 1988, 73: 29-

79 Li Y, Yin Y, Liu G, et al. Estimation of the major source and sink of methylmercury in the Florida Everglades. Environ Sci Technol, 2012, 46: 5885-5893

80 Oremland R S, Culbertson C W, Winfrey M R. Methylmercury decomposition in sediments and bacterial cultures: Involvement of methanogens and sulfate reducers in oxidative demethylation. Appl Environ Microbiol, 1991, 57: 130-137

81 Baldi F, Pepi M, Filippelli M. Methylmercury resistance in Desulfovibrio desulfuricans strains in relation to methylmercury degradation. Appl Environ Microbiol, 1993, 59: 2479-2485

82 Oremland R S, Miller L G, Dowdle P, et al. Methylmercury oxidative degradation potentials in contaminated and pristine sediments of the carson river, nevada. Appl Environ Microbiol, 1995, 61: 2745-2753

83 Inoko M. Studies on the photochemical decomposition of organomercurials-methylmercury(II) chloride. Environ Pollut B, 1981, 2: $3-10$

84 Suda I, Takahashi H. Degradation of methyl and ethyl mercury into inorganic mercury by other reactive oxygen species besides hydroxyl radical. Arch Toxicol, 1992, 66: 34-39

85 Suda I, Suda M, Hirayama K. Degradation of methyl and ethyl mercury by singlet oxygen generated from sea-water exposed to sunlight or ultraviolet-light. Arch Toxicol, 1993, 67: 365-368

86 Marvin-DiPasquale M, Agee J, McGowan C, et al. Methyl-mercury degradation pathways: A comparison among three mercury-impacted ecosystems. Environ Sci Technol, 2000, 34: 4908-4916

87 Gardfeldt K, Sommar J, Stromberg D, et al. Oxidation of atomic mercury by hydroxyl radicals and photoinduced decomposition of methylmercury in the aqueous phase. Atmos Environ, 2001, 35: 3039-3047

88 Chen J, Pehkonen S O, Lin C J. Degradation of monomethylmercury chloride by hydroxyl radicals in simulated natural waters. Water Res, 2003, 37: 2496-2504

89 Lehnherr I, St Louis V L. Importance of ultraviolet radiation in the photodemethylation of methylmercury in freshwater ecosystems. Environ Sci Technol, 2009, 43: 5692-5698

90 Hammerschmidt C R, Fitzgerald W F. Iron-mediated photochemical decomposition of methylmercury in an Arctic Alaskan lake. Environ Sci Technol, 2010, 44: 6138-6143

91 Zhang T, Hsu-Kim H. Photolytic degradation of methylmercury 
enhanced by binding to natural organic ligands. Nat Geosci, 2010, 3: 473-476

92 Khan M A K, Wang F Y. Chemical demethylation of methylmercury by selenoamino acids. Chem Res Toxicol, 2010, 23: 1202-1206

93 Asaduzzaman A, Schreckenbach G. Degradation mechanism of methyl mercury selenoamino acid complexes: A computational study. Inorg Chem, 2011, 50: 2366-2372

94 Marvin-DiPasquale M C, Oremland R S. Bacterial methylmercury degradation in Florida Everglades peat sediment. Environ Sci Technol, 1998, 32: 2556-2563

95 Schaefer J K, Yagi J, Reinfelder J R, et al. Role of the bacterial organomercury lyase (MerB) in controlling methylmercury accumulation in mercury-contaminated natural waters. Environ Sci Technol, 2004, 38: 4304-4311

96 Allard B, Arsenie I. Abiotic reduction of mercury by humic substances in aquatic system-an important process for the mercury cycle. Water Air Soil Pollut, 1991, 56: 457-464

97 Black F J, Poulin B A, Flegal A R. Factors controlling the abiotic photo-degradation of monomethylmercury in surface waters. Geochimica Et Cosmochimica Acta, 2012, 84: 492-507

98 Chandan P. Mercury Isotope Fractionation During Aqueous Photoreduction of Methylmercury in Presence of Different Types and Amounts of Dissolved Organic Matter. Toronto: University of Toronto, 2011

99 Han S, Obraztsova A, Pretto P, et al. Biogeochemical factors affecting mercury methylation in sediments of the Venice Lagoon, Italy. Environ Toxicol Chem, 2007, 26: 655-663

100 Hammerschmidt C R, Fitzgerald W F. Geochemical controls on the production and distribution of methylmercury in near-shore marine sediments. Environ Sci Technol, 2004, 38: 1487-1495

101 Benoit J M, Gilmour C C, Mason R P. The influence of sulfide on solid phase mercury bioavailability for methylation by pure cultures of Desulfobulbus propionicus (1pr3). Environ Sci Technol, 2001, 35: 127-132

102 Hintelmann H, Keppel-Jones K, Evans R D. Constants of mercury methylation and demethylation rates in sediments and comparison of tracer and ambient mercury availability. Environ Toxicol Chem, 2000, 19: 2204-2211

103 Farrell R E, Huang P M, Germida J J. Biomethylation of mercury(II) adsorbed on mineral colloids common in freshwater sediments. Appl Organomet Chem, 1998, 12: 613-620

104 Morel F M M, Kraepiel A M L, Amyot M. The chemical cycle and bioaccumulation of mercury. Annu Rev Ecol Syst, 1998, 29: 543-566

105 Drott A, Lambertsson L, Bjorn E, et al. Importance of dissolved neutral mercury sulfides for methyl mercury production in contaminated sediments. Environ Sci Technol, 2007, 41: 2270-2276

106 Wolfenden S, Charnock J M, Hilton J, et al. Sulfide species as a sink for mercury in lake sediments. Environ Sci Technol, 2005, 39: 66446648

107 Ullrich S M, Tanton T W, Abdrashitova S A. Mercury in the aquatic environment: A review of factors affecting methylation. Crit Rev Environ Sci Technol, 2001, 31: 241-293

108 Fitzgerald W F, Lamborg C H, Hammerschmidt C R. Marine biogeochemical cycling of mercury. Chem Rev, 2007, 107: 641-662

109 Benoit J M, Gilmour C C, Mason R P, et al. Sulfide controls on mercury speciation and bioavailability to methylating bacteria in sediment pore waters. Environ Sci Technol, 1999, 33: 951-957

110 Benoit J M, Mason R P, Gilmour C C. Estimation of mercury-sulfide speciation in sediment pore waters using octanol-water partitioning and implications for availability to methylating bacteria. Environ Toxicol Chem, 1999, 18: 2138-2141

111 Benoit J M, Gilmour C C, Mason R P. Aspects of bioavailability of mercury for methylation in pure cultures of Desulfobulbus propionicus (1pr3). Appl Environ Microbiol, 2001, 67: 51-58

112 Lin C C, Jay J A. Mercury methylation by planktonic and biofilm cultures of Desulfovibrio desulfuricans. Environ Sci Technol, 2007,

\section{1: 6691-6697}

113 Hammerschmidt C R, Fitzgerald W F, Balcom P H, et al. Organic matter and sulfide inhibit methylmercury production in sediments of New York/New Jersey Harbor. Mar Chem, 2008, 109: 165-182

114 Schaefer J K, Morel F M M. High methylation rates of mercury bound to cysteine by Geobacter sulfurreducens. Nat Geosci, 2009, 2: 123-126

115 Schaefer J K, Rocks S S, Zheng W, et al. Active transport, substrate specificity, and methylation of $\mathrm{Hg}$ (II) in anaerobic bacteria. Proc Natl Acad Sci USA, 2011, 108: 8714-8719

116 Ravichandran M. Interactions between mercury and dissolved organic matter-A review. Chemosphere, 2004, 55: 319-331

117 Baughman G L, Gordon J A, Wolfe N L, et al. Chemistry of Organomercurials in Aquatic Systems. Washington DC: US Environmental Protection Agency, 1973

118 Akagi H, Mortimer D C, Miller D R. Mercury methylation and partition in aquatic systems. Bull Environ Contam Toxicol, 1979, 23: $372-376$

119 Gilmour C C, Riedel G S. Measurement of $\mathrm{Hg}$ methylation in sediments using high specific-activity $\mathrm{Hg}-203$ and ambient incubation. Water Air Soil Pollut, 1995, 80: 747-756

120 Koron N, Bratkic A, Guevara S R, et al. Mercury methylation and reduction potentials in marine water: An improved methodology using (197) Hg radiotracer. Appl Radiat Isotop, 2012, 70: 46-50

121 Monperrus M, Tessier E, Point D, et al. The biogeochemistry of mercury at the sediment-water interface in the Thau Lagoon. 2. Evaluation of mercury methylation potential in both surface sediment and the water column. Estuar Coast Shelf Sci, 2007, 72: 485-496

122 Hintelmann H, Evans R D, Villeneuve J Y. Measurement of mercury methylation in sediments by using enriched stable mercury isotopes combined with methylmercury determination by gas-chromatography inductively-coupled plasma-mass spectrometry. J Anal At Spectrom, 1995, 10: 619-624

123 Hintelmann H, Harris R, Heyes A, et al. Reactivity and mobility of new and old mercury deposition in a Boreal forest ecosystem during the first year of the METAALICUS study. Environ Sci Technol, 2002, 36: 5034-5040

124 Lambertsson L, Lundberg E, Nilsson M, et al. Applications of enriched stable isotope tracers in combination with isotope dilution GC-ICP-MS to study mercury species transformation in sea sediments during in situ ethylation and determination. J Anal At Spectrom, 2001, 16: 1296-1301

125 Martin-Doimeadios R C, Tessier E, Amouroux D, et al. Mercury methylation/demethylation and volatilization pathways in estuarine sediment slurries using species-specific enriched stable isotopes. Mar Chem, 2004, 90: 107-123

126 Whalin L M, Mason R P. A new method for the investigation of mercury redox chemistry in natural waters utilizing deflatable Teflon (R) bags and additions of isotopically labeled mercury. Anal Chim Acta, 2006, 558: 211-221

127 Monperrus M, Gonzalez P R, Amouroux D, et al. Evaluating the potential and limitations of double-spiking species-specific isotope dilution analysis for the accurate quantification of mercury species in different environmental matrices. Anal Bioanal Chem, 2008, 390: 655-666

128 Bridou R, Monperrus M, Gonzalez P R, et al. Simultaneous determination of mercury methylation and demethylation capacities of various sulfate-reducing bacteria using species-specific isotopic tracers. Environ Toxicol Chem, 2011, 30: 337-344

129 Hintelmann H, Evans R D. Application of stable isotopes in environmental tracer studies-Measurement of monomethylmercury $\left(\mathrm{CH}_{3} \mathrm{Hg}^{+}\right)$by isotope dilution ICP-MS and detection of species transformation. Fresen J Anal Chem, 1997, 358: 378-385

130 Gray J E, Hines M E, Biester H. Mercury methylation influenced by areas of past mercury mining in the Terlingua district, Southwest Texas, USA. Appl Geochem, 2006, 21: 1940-1954

Open Access This article is distributed under the terms of the Creative Commons Attribution License which permits any use, distribution, and reproduction in any medium, provided the original author(s) and source are credited. 